\title{
Ureogenic function and periodic urea excretion in a gobiid
}

\section{fish, Mugilogobius abei}

\author{
"KATSUYA IWATA', MAKIKO KAJIMURA² AND TATSUYA SAKAMOTO 3 \\ 'Biological Labo. Faculty of Education, Wakayama University, Wakayama, 640-8510, Japan Katsuiw@ \\ centerwakayama-u.ac.jp), '2Department of Bio-and Geo-Sciences, Graduate School of Science Osaka City \\ University, 558-8585, Japan, ${ }^{3}$ Graduate school of Biosphere Science, Hiroshima University, Higasi-Hiroshima, \\ 739, Japan
}

SUMMARY: $M$. abei has a high ability to produce a large amount of urea, when exposed to $2 \mathrm{mM}$ $\mathrm{NH}_{4} \mathrm{HCO}_{3}$ or $1 \mathrm{mM}^{15} \mathrm{~N}$ - $\left(\mathrm{NH}_{4}\right)_{2} \mathrm{SO}_{4}$ solution. After exposure to ${ }^{15} \mathrm{~N}$-ammonia, ${ }^{15} \mathrm{~N}$-concentration of the amide- $\mathrm{N}$ in glutamine in tissues was virtually the same as that of ammonia- $\mathrm{N}$, which were about 2-fold that of urea- $N$ in the tissues as well as in the excreta. Glutamine contents and glutamine synthetase activities in the liver and muscle increased greatly following exposure to ammonia. CPSasellImRNA expression as well as CPSaselll activity was found to be present in muscle, skin and gill, but not in liver, spleen and intestine. Furthermore, it was found that $M$. abei excreted urea with a periodic rhythm which might be mediated by a periodic enhancement of urea permeability at excretion sites.

\section{KEY WORD: CPSaselll, gobiid fish, diel periodicity, ornithine-urea cycle, urea, ureogenesis}

\section{INTRODUCTION}

Only a very few teleost species are known to produce urea via ornithine-urea cycle (O-UC). Among the ureogenic teleosts discovered to date, ${ }^{1,2,3)}$ the Lake Magadi tilapia Alcolapia grahami is known to be the only teleostean fish excreting all its nitrogenous waste as urea, i.e. ureotely. ${ }^{4)}$ The other ureogenic teleosts are a functional ureogenesis, i.e. they can produce urea, only when exposed to adverse conditions such as hyper ammonia environment and crowding. Recently, we have revealed that a goby, Mugilogobius abei, Abehaze in Japanese has a high ability to produce urea through $\mathrm{O}-U \mathrm{UC}$, when the fish is exposed to 2 $\mathrm{mM} \mathrm{NH} \mathrm{HCO}_{3}{ }^{5)}$ This is the first finding of a ureogenic goby among gobiid fishes in the world. M.abei is a small goby (normally less than $1 \mathrm{~g}$ ) and its external features are those of water breathing gobiid fishes. M.abei lives in mud flat around the mouth of rivers, where Tobihaze, Periophthalumus modestus also lives. M.abei can be found out even in a heavily polluted area receiving sewage, where it is the sole fish fauna. In such place, the black mud covers over the surface, so that redox potential values in the mud are usually strong negative. In the interstitial water of such sediment, ammonia concentration is usually very high occasionally reaching $2 \mathrm{mM}$ or more. Indeed, this fish can live

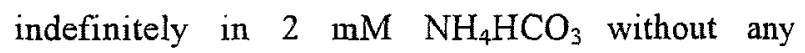
adverse symptoms, but the majority of fish died in 4 $\mathrm{mM} \mathrm{NH} \mathrm{NHCO}_{3}$ within 24 hours. In this paper, we compare several aspects for urea production of $M$. $a b e i$ with those of other teleostean species including ureotely or ureogenic ones.

\section{AMMONIOTELIC VS UREOGENIC}

Fig.1 shows a comparison of urea excretion between a ureogenic teleost, $M$. abei and an ammoniotelic teleost, $P$. modestus, when they are exposed to $2 \mathrm{mM} \mathrm{NH}_{4} \mathrm{HCO}_{3}$ dissolved in $20 \%$ sea water (SW). Urea excretion in $M$. abei following exposure to ammonia increased with time and reached 7-8-fold higher levels of the control fish $(20 \% \mathrm{SW})$ on day 4 through 8 . While those levels of 
$P$. modestus remained unchanged, although an ability for ammonia tolerance of $P$. modestus was similar to that of $M$. abei.

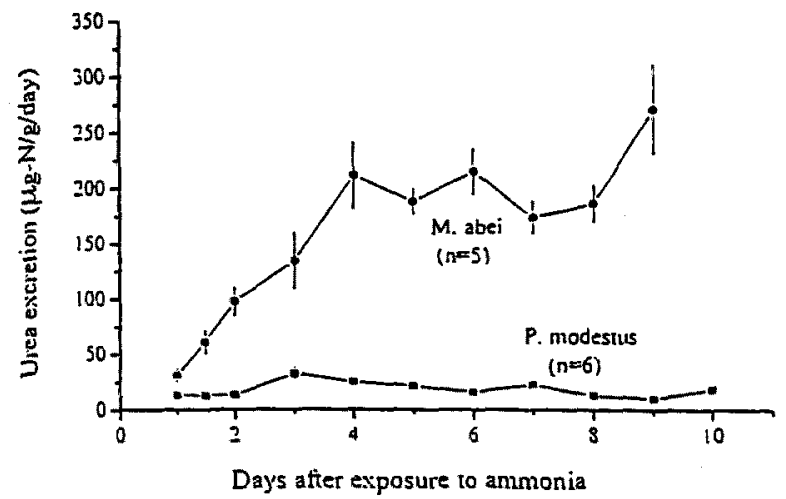

Fig. 1 Comparison of urea excretion between ureogenic ( $M$. abei) and ammoniotelic (P. modestus) teleosts following exposure to $2 \mathrm{mM} \mathrm{NH}_{4} \mathrm{HCO}_{3}$. Both species have similar high ammonia tolerance.

To make it clear whether $M$. abei can efficiently incorporate external ammonia into the urea molecule, the fish was exposed to ${ }^{15} \mathrm{~N}-\left(\mathrm{NH}_{4}\right)_{2} \mathrm{SO}_{4}$ solution $\left({ }^{15} \mathrm{~N}\right.$ - $\left(\mathrm{NH}_{4}\right)_{2} \mathrm{SO}_{4}$ dissolved in $10 \%$ sea water and adjusted $\mathrm{pH}$ to 8 with $\mathrm{NaHCO}_{3}$ ). Following exposure to ${ }^{15} \mathrm{~N}-\left(\mathrm{NH}_{4}\right)_{2} \mathrm{SO}_{4}$ solution, increasing manner of urea excretion with time was similar to that of Fig.l and ${ }^{15} \mathrm{~N}$-concentration in excreted urea increased with time and reached a plateau level at day 3 to 4 . After $M$. abei was exposed to ${ }^{15} \mathrm{~N}$-ammonia solution for 4 days, liver, muscle and whole remaining tissues were dissected, and ${ }^{15} \mathrm{~N}$-concentration in ammonia- $\mathrm{N}$, amide- $\mathrm{N}$ in glutamine, urea- $\mathrm{N}$ and $\alpha$-amino- $N$ in amino acid fraction in these tissue extracts were measured. ${ }^{15} \mathrm{~N}$-concentration in ammonia- $\mathrm{N}$ and amide- $\mathrm{N}$ in glutamine were similar in all the tissues examined (60-64 atom\%excess), but that of $\alpha$-amino- $\mathrm{N}$ was low (2-3 atom $\%$ excess). ${ }^{15} \mathrm{~N}$-concnetration in urea- $\mathrm{N}$ in tissues as well as the excreta showed just the middle values between ammonia- and amide- $\mathrm{N}$ and $\alpha$-amino- $N$. These results indicate that ammonia entered in $M$. abei is rapidly incorporated into amide- $\mathrm{N}$ in glutamine, which is then converted to half part of urea- $\mathrm{N}$. Glutamine formation is particularly important for urea synthesis, since carbamoyl phosphate synthetase III (CPSaseIII), the key enzyme of $\mathrm{O}-\mathrm{UC}$, requires glutamine as nitrogen donor.

\section{SITE OF UREA PRODUCTION}

Table 1 shows the activities of enzymes related to O-UC in various tissues in $M$. abei. CPSaseIII activity could be detected in skin, gill and muscle, but liver had virtually no activity. Similarly, when CPSaseIIImRNA expression in various tissues of $M$. abei was surveyed by RT-PCR using specific primer of $M$. abei, CPSaseIIImRNA expression was found to be present in muscle, skin and gill, but not in liver, intestine and spleen. In accord with relatively higher CPSaseIII activities, skin and gill also have higher ornithine transcarbamoylase (OTCase) activities (Table 1). Thus, $M$. abei has a fully O-UC enzymes, but exhibited two unusual aspects. Firstly, CPSaseIII activities as well as CPSasellI gene expression were found in extra-hepatic tissues. Secondly, when CPSaseIII is assayed with ammonia as nitrogen donor, enzymes from skin and muscle exhibited similar levels to those of glutamine.

Table 1 Activities of enzymes related to OUC in liver, muscle, skin and gill following exposure to ammonia for 4 to sdays.

\begin{tabular}{|c|c|c|c|c|}
\hline \multirow{3}{*}{$\begin{array}{l}\text { CPSaseIII } \\
\text { with glutamine }\end{array}$} & Liver & Muscle & Skin & Gill \\
\hline & $\mathrm{nmol} / \mathrm{min} / \mathrm{g}$ & $\mathrm{nmol} / \mathrm{min} / \mathrm{g}$ & $\mathrm{nmol} / \mathrm{min} / \mathrm{g}$ & $\mathrm{nmol} / \mathrm{min} / \mathrm{g}$ \\
\hline & $0.1 \pm 0.0$ & $2.7 \pm 0.7$ & $2.9 \pm 0.4$ & $1.9 \pm 0.2$ \\
\hline \multirow{2}{*}{ with ammonia } & N.D. & $1.5 \pm 0.3$ & $2.2 \pm 0.5$ & N.D. \\
\hline & $\mu \mathrm{mol} / \mathrm{min} / \mathrm{g}$ & $\mu \mathrm{mol} / \mathrm{min} / \mathrm{g}$ & $\mu \mathrm{mol} / \mathrm{min} / \mathrm{g}$ & $\mu \mathrm{mol} / \mathrm{min} / \mathrm{g}$ \\
\hline OTCase & $0.13 \pm 0.02$ & $0.63 \pm 0.13$ & $3.13 \pm 1.12$ & $3.29 \pm 1.21$ \\
\hline ASSase + ASLase & $0.04 \pm 0.01$ & $0.12 \pm 0.03$ & $0.09=0.00$ & $0.26 \pm 0.04$ \\
\hline ARGase & $7.16 \pm 1.07$ & $0.03 \pm 0.01$ & $0.40 \pm 0.30$ & $2.71 \pm 0.54$ \\
\hline \multicolumn{5}{|c|}{ Means \pm S.E.M. $(n=4-8)$, N.D. (not determined) } \\
\hline \multicolumn{5}{|c|}{ ASSase, argininosuccinate synthetase; ASLase, argininosuccinate lyase; } \\
\hline \multicolumn{5}{|l|}{ ARGase, arginase. } \\
\hline \multicolumn{5}{|c|}{ Activities of enzymes in O-UC in the tissues of ammonia exposed fish were } \\
\hline
\end{tabular}

Among the ureogenic teleosts studied to date, except the Lake Magadi tilapia, the liver of ureogenic species is primary responsible for urea production as in mammal. ${ }^{2,3,7)}$ However, the muscle of the Lake Magadi tilapia is known to have very high CPSase III activity and to be a main site of urea production. ${ }^{6)}$ Furthermore, CPSaselII 
from the muscle of the Lake Magadi tilapia has a high capacity to use ammonia as a substrate, in addition to glutamine as the more usual substrate. Thus, CPSaselII in muscle and skin from $M$. abei seems to have similar properties to those of the Lake Magadi tilapia, although activity in $M$. abei is extremely low as compared with that of the Lake Magadi tilapia. In $M$. abei, the muscle seems to play very important role for overall urea production in fish body, when tissue mass is taken into account

\section{STORAGE OF AMMONIA AND GLUTAMINE FORMATION IN MUSCLE}

Table 2 shows changes in ammonia, urea and free amino acids contents in tissue extracts following exposure to ammonia. Ammonia and urea in muscle and liver increased greatly following exposure to ammonia. Among free amino acids examined, only glutamine showed a great increase in muscle and liver of the exposed fish. The level of alanine was low compared with glutamine, but significantly increased in muscle. On the other hand, other amino acid levels remained unchanged following exposure to ammonia. Ammonia and glutamine in muscle of the exposed fish account $61 \%$ and $65 \%$ of those in the whole body, respectively (if muscle make up $50 \%$ of body mass).

Table 2 Changes in ammonia, urea and free amino acids in liver and muscle following exposure to ammonia

\begin{tabular}{|c|c|c|c|c|}
\hline \multirow[b]{4}{*}{ Tau } & \multicolumn{2}{|c|}{ Liver } & \multicolumn{2}{|c|}{ Muscle } \\
\hline & \multirow{2}{*}{$\frac{\text { Control }}{\mu \mathrm{mol} / \mathrm{g}}$} & \multirow{2}{*}{$\frac{\text { Ammonia }}{\mu \mathrm{mol} / \mathrm{g}}$} & \multirow{2}{*}{$\frac{\text { Control }}{\mu \mathrm{mol} / \mathrm{g}}$} & \multirow{2}{*}{$\frac{\text { Ammonia }}{\mu \mathrm{mol} / \mathrm{g}}$} \\
\hline & & & & \\
\hline & $7.74 \pm 0.94$ & $7.01 \pm 0.64$ & $12.6 \pm 1.11$ & $9.81 \pm 0.32$ \\
\hline Asp & $0.33 \pm 0.05$ & $0.25 \pm 0.02$ & $0.37 \pm 0.08$ & $0.23 \pm 0.06$ \\
\hline Thr & $0.55 \pm 0.06$ & $0.34 \pm 0.03$ & $1.14 \pm 0.13$ & $0.94 \pm 0.18$ \\
\hline Ser & $0.51 \pm 0.06$ & $0.34 \pm 0.04$ & $0.77 \pm 0.10$ & $0.74 \pm 0.07$ \\
\hline Glu & $2.89 \pm 0.63$ & $1.97 \pm 0.24$ & $0.58 \pm 0.06$ & $0.68 \pm 0.14$ \\
\hline Gin & $1.73 \pm 0.59$ & $5.60 \pm 1.22$ & $* * 1.12 \pm 0.20$ & $6.86 \pm 1.53$ \\
\hline Pro & $0.59 \pm 0.16$ & $0.33 \pm 0.12$ & $0.61 \pm 0.13$ & $0.37 \pm 0.11$ \\
\hline Gly & $0.89 \pm 0.26$ & $0.58 \pm 0.18$ & $9.39 \pm 1.38$ & $8.74 \pm 0.73$ \\
\hline \multirow[t]{2}{*}{$\mathrm{Ala}$} & $0.97 \pm 0.28$ & $0.81 \pm 0.11$ & $0.87 \pm 0.21$ & $1.89 \pm 0.29$ \\
\hline & $\mu \mathrm{mol}-\mathrm{N} / \mathrm{g}$ & $\mu \mathrm{mol}-\mathrm{N} / \mathrm{g}$ & $\mu \mathrm{mol}-\mathrm{N} / \mathrm{g}$ & $\mu \mathrm{mol}-\mathrm{N} / \mathrm{g}$ \\
\hline $\mathrm{Am}$ & $3.59 \pm 0.40$ & $7.83 \pm 1.00$ & $* \overline{4.98 \pm 1.04}$ & $13.95 \pm 1.16$ \\
\hline Urea & $3.51 \pm 0.84$ & $2.04 \pm 0.42$ & $2.85 \pm 1.31$ & $6.81 \pm 1.35$ \\
\hline
\end{tabular}

Glutamine synthetase activity (GSase) in liver and muscle increased greatly following exposure to ammonia. Tissue specific activity (unit/g tissue mass) for GSase was 15-fold higher in liver than that in muscle. However, total muscular activity of the ammonia-exposed fish was approximately 2 -fold larger than total hepatic activity. These facts strongly suggest that the conversion of ammonia into the amide- $\mathrm{N}$ in glutamine, i.e. the first step of ammonia detoxification, occurs mainly in muscle. Thus, in $M$. $a b e i$, muscle plays a pivotal role not only in converting a large amount of ammonia into the amide $-\mathrm{N}$ in glutamine, but also in feeding this nitrogen into O-UC as the primary. substrate for CPSaseIII.

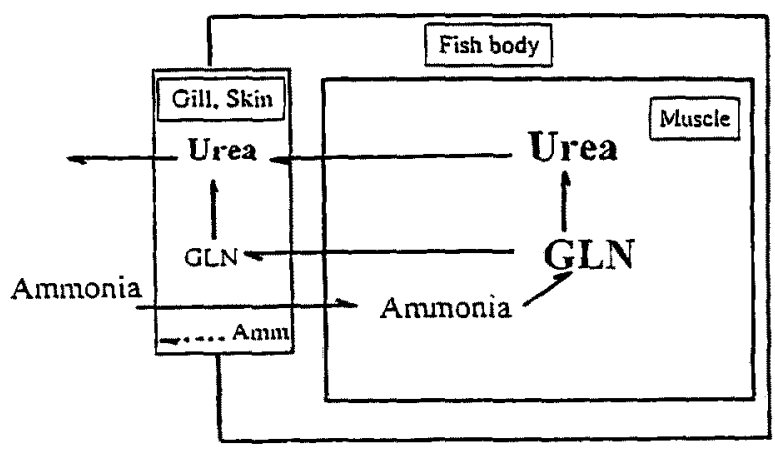

Fig. 2 A hypothetical role of muscle, skin and gill of $M$. $a b e i$ in producing urea under a hyper ammonia environment.

Fig. 2 shows a hypothetical role of muscle, gill and skin for urea production under a hyper ammonia environment. When ammonia elimination from gill or skin is disturbed under a hyper ammonia environment, ammonia entered to fish body accumulates mainly in muscle, and a part of ammonia is then converted into glutamine and finally, amide- $\mathrm{N}$ in glutamine or probably ammonia is converted to urea molecule mainly in muscle. Furthermore, glutamine formed in muscle is carried away to gill or skin through circulation and then converted there to urea for excreting it. Thus. $M$. abei has unusual properties about urea production. Firstly, extra-hepatic tissues, particularly muscle are main site of urea production. Secondly, multiple tissues seem to cooperate for producing urea when ammonia elimination from the fish into environ- 
ment is disturbed.

Finally, another unique aspect of urea excretion in $M$. abei is in that this goby excretes urea with a daily periodicity under a $12 \mathrm{~h}$ light-dark cycle as shown in Fig. 3. A peak of urea excretion always occurred the middle of light phase. The periodicity in urea excretion was maintained even in continuous darkness, suggesting that this periodicity is controlled by a circadian rhythm. In contrast, the daily periodicity was not found in ammonia excretion. Among the ureogenic teleosts studied to date, the gulf toadfish, Opsanus beta is known to excrete urea once in a day, but with an irregular pulsatile manner. Therefore, the daily periodicity of urea excretion as found in $M$. abei seens to be unique even among ureogenic species. There is no enough space to write the detail, but in brief, some evidences we have found suggest that the periodicity for urea excretion is not caused by a periodic production of urea, but a periodic activation for urea permeability at the sites of excretion, probably gill and/or skin. However, the precise mechanism and role of periodic urea excretion in this goby are still unclear. Further studies are required.

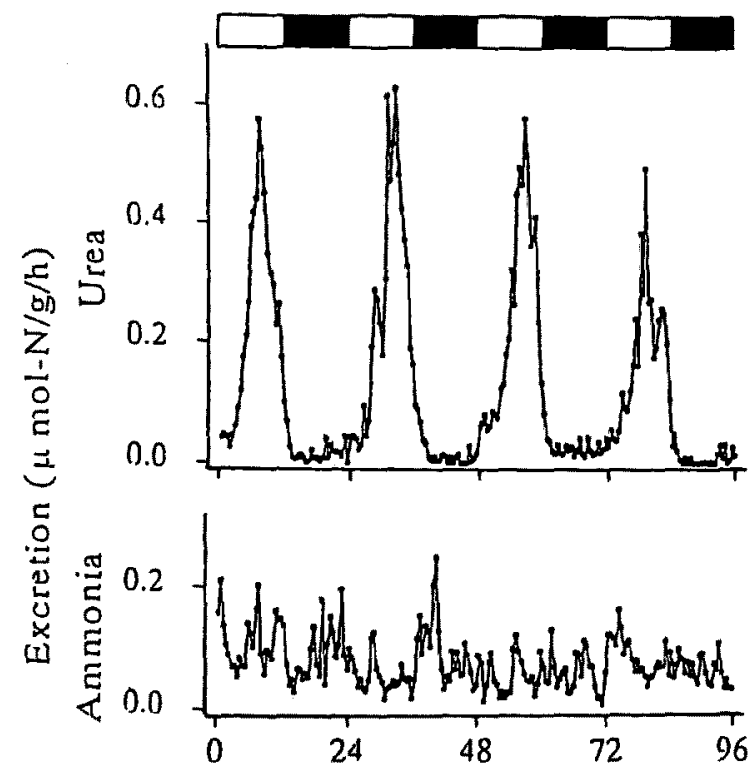

Fig. 3 Urea and ammonia excretion of $M$. abei under a $12 \mathrm{~h}$ light-dark cycle. A daily periodicity was found only in urea excretion.

\section{ACKNOWLEDGMENT}

This research was partly supported by Grants-in-Aid from the Japan Society for the Promotion of Science and the Fisheries Agency of Japan.

\section{REFERENCES}

1. Walsh JP, Danulat E, Mommsen TP. Variation in urea excretion in the gulf toadfish Opsanus beta. Mar. Biol. 1990; 106: 323-328.

2. Saha N, Ratha BK. Active ureogenesis in a freshwater air-breathing teleosts, Heteropneustes fossilis. J. Exp. Zool. 1987; 241: 137-141.

3. Saha $N$, Das L, Dutta S. Types of carbamoyl phosphate synthetase and subcellular localization of urea cycle and related enzymes in air-breathing walking catfish, Clarias batrachus. J. Exp. Zool. 1999; 283:121-130.

4. Randall DJ, Wood CM, Perry SF, Bergman H, Maloiy GMO, Mommsen TP, Wright PA. Urea excretion as a strategy for survival in a fish living in a very alkaline environment. Nature 1989; 337:165-166.

5. Iwata $\mathrm{K}$, Kajimura $M$, Sakamoto $T$. Fuctional ureogenesis in the gobiid fish, Mugilogobius abei. J. Exp. Biol. 2000; 203: 3703-3715.

6. Lindley TE, Scheiderer CL, Walsh PJ, Wood CM, Bergman $\mathrm{HL}$, Bergman $\mathrm{AL}$, Laurent $\mathrm{P}$, Wilson $\mathrm{P}$, Anderson PM. Muscle as the primary site of urea cycle enzyme activity in an alkaline lake-adapted tilapia Oreochromis alcalicus grahami. J. Biol. Chem. 1999; 274: 29858-29861.

7. Walsh PI, Milligan CL. Effects of feeding and confinement on nitrogen metabolism and excretion in the gulf toadfish Opsanus beta. J. Exp. Biol. 1995; 198:1559-1566. 